\title{
Case Report of a Patient with
}

\section{Swyer-James-MacLeod Syndrome Undergoing Breast Surgery under Regional Anaesthesia and Review of Literature}

\author{
Jieyin Xing*, Sze Ying Thong \\ Department of Anaesthesia, Singapore General Hospital, Singapore \\ Email: *xing.jieyin@singhealth.com.sg
}

How to cite this paper: Xing, J.Y. and Thong, S.Y. (2018) Case Report of a Patient with Swyer-James-MacLeod Syndrome Undergoing Breast Surgery under Regional Anaesthesia and Review of Literature. Open Journal of Anesthesiology, 8, 66-79. https://doi.org/10.4236/ojanes.2018.83007

Received: February 7, 2018

Accepted: March 17, 2018

Published: March 20, 2018

Copyright $\odot 2018$ by authors and Scientific Research Publishing Inc. This work is licensed under the Creative Commons Attribution International License (CC BY 4.0).

http://creativecommons.org/licenses/by/4.0/

(c) (i) Open Access

\begin{abstract}
Swyer-James-MacLeod Syndrome is a rare acquired pulmonary disorder that develops secondary to infectious etiologies in early childhood. Patients who are affected have the potential of developing perioperative respiratory complications. While regional anaesthetic techniques are often performed as adjuncts to general anaesthesia, there is less data on breast operations being done solely under regional anaesthesia. We herein describe a patient with Swyer-James-MacLeod Syndrome who underwent breast lesion wide excision under combined paravertebral and pectoral nerves block, supplemented with propofol infusion for sedation. Choice of blocks was decided upon based on knowledge on the anatomy. Sole regional anaesthetic techniques have been the safest approach in some circumstances and should always be considered in patients who are of high risk under general anaesthesia.
\end{abstract}

\section{Keywords}

Breast Surgery, Regional Anaesthesia, Paravertebral Nerve Block, Pecs Block, Swyer-James-MacLeod Syndrome

\section{Introduction}

Swyer-James-MacLeod Syndrome (SJMS) is a rare, acquired post-infectious condition characterised by emphysematous changes or bronchiectasis which may lead to fibrosis to cause pulmonary capillary bed destruction. Patients with severe lung disease presenting for anaesthesia are a challenge because intraoperative and postoperative respiratory complications are more common in them, and these may lead to prolonged hospital stay and increased mortality. Regional 
anaesthetic techniques are often used adjunctively for breast surgeries under general anaesthesia (GA), but there are limited reports on breast surgeries done solely under regional anaesthesia (RA). We describe a patient with SJMS who successfully underwent breast surgery under regional anaesthesia.

Written consent was obtained from the patient for publication of this case report.

\section{Case Report}

The patient is a 51-year-old female with a history of Swyer-James-MacLeod Syndrome (SJMS) who required stereotactic hook-wire localization, wide excision of left breast micro calcifications. Her only surgical history was an uneventful laparoscopic bilateral salpingo-oophorectomy earlier in the same year performed under combined spinal-epidural, for which she required postoperative intensive care monitoring. Although she was NYHA class 2, her recent lung function test was grossly abnormal: FEV1 $1.04 \mathrm{~L}$ (46\% predicted), FVC $1.97 \mathrm{~L}$ (76\% predicted) and FEV/FVC ratio 53\%. Her chest X-ray showed changes congruent with her diagnosis: hypoplastic, bronchiectatic left lung and bronchial wall thickening in the right lung (Figure 1).

She was planned for surgery under regional anaesthesia. Single shot paravertebral, medial and lateral pectoral nerve blocks were performed under conscious sedation with intravenous midazolam $1 \mathrm{mg}$ and fentanyl $50 \mathrm{mcg}$. She was first positioned prone and left T3 and T4 paravertebral spaces were located with ultrasound (Figure 2 and Figure 3). Paravertebral block was performed with a 50 mm Pajunk Sono Plex Stim cannula and Sonosite Edge HFL50x transducer in

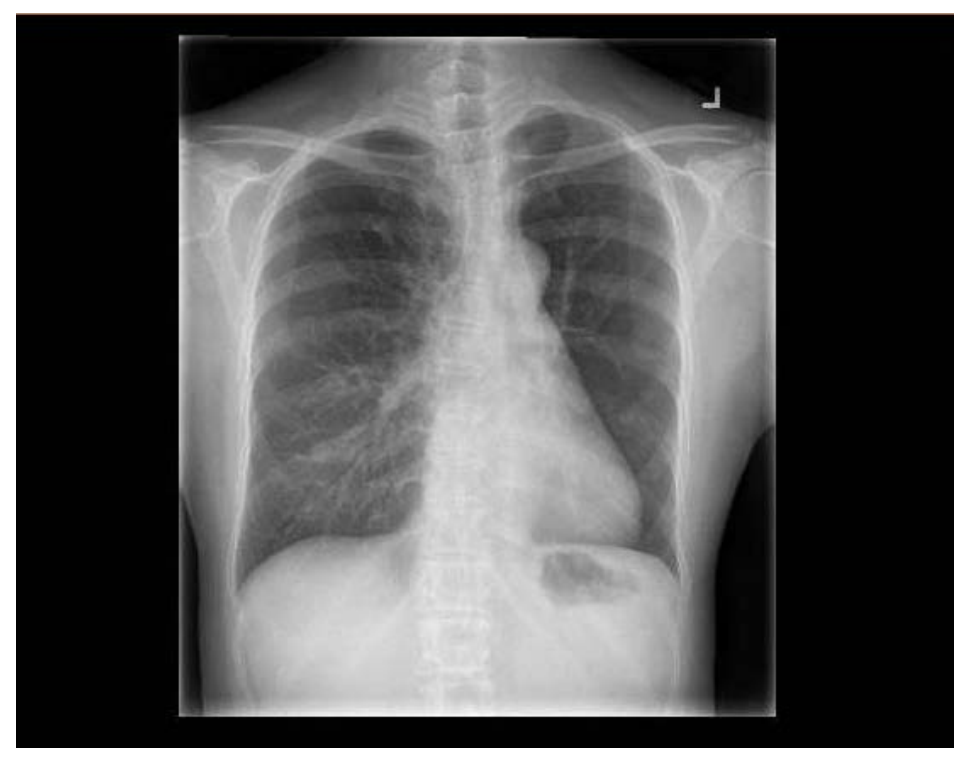

Figure 1. There are bronchiectatic changes in the left lower zone with some cystic lucencies and airway wall thickening. There is reduced volume of the left lung with relatively lucent appearance of the left hemithorax. Some bronchial wall thickening is also present in the right lung. 


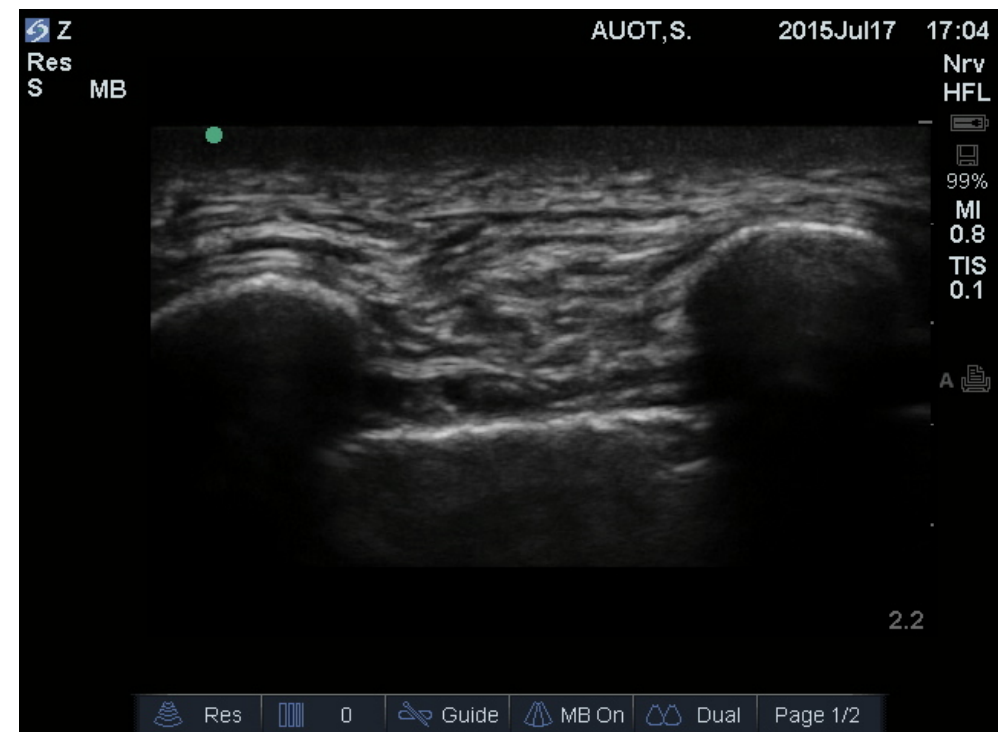

Figure 2. Ultrasound image of left paravertebral space with the transducer in the sagittal plane.

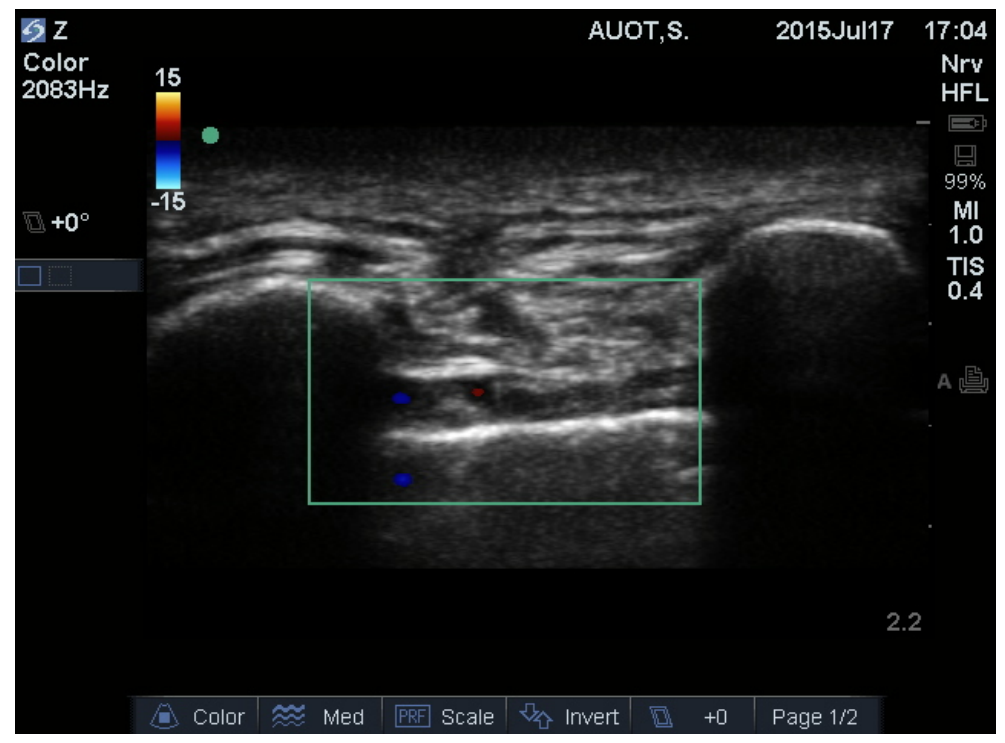

Figure 3. Ultrasound image of the same space, with frame indicating boundaries of colour Doppler applied, to reveal location of blood vessels before injection using out-of-plane technique.

the sagittal plane using out of plane technique. $100 \mathrm{mg}$ lignocaine $(5 \mathrm{mcg} / \mathrm{ml}$ adrenaline) and $50 \mathrm{mg}$ ropivacaine in $10 \mathrm{ml}$ were administered to each level. She was then positioned supine for medial and lateral pectoral nerve block with $8 \mathrm{ml}$ of $200 \mathrm{mg}$ lignocaine ( $5 \mathrm{mcg} / \mathrm{ml}$ adrenaline) under in-plane ultrasound guidance in the infraclavicular area.

Sedation was started at patient's request with propofol target controlled infusion, Schneider mode at effect site concentration of $1.8 \mathrm{ng} / \mathrm{ml}$. A $3 \mathrm{~cm}$ radial skin incision was made 18 minutes after the completion of regional anaesthesia. Planned wide excision proceeded smoothly with excellent surgical condition. 
Total surgical time was 20 minutes and patient recovered well enough for same-day discharge.

\section{Discussion}

Swyer-James-MacLeod Syndrome (SJMS), which was first described in 1953 by Swyer and James, and further detailed by MacLeod, is a rare acquired condition secondary to viral bronchiolitis and pneumonitis in childhood [1]. The condition manifests as a post-infectious bronchiolitis obliterans characterized by emphysematous changes or bronchiectasis which may lead to fibrosis in both bronchioles and interalveolar septum, causing pulmonary capillary bed destruction [2]. Patients' symptomology may range from asymptomatic with incidental diagnostic radiographical findings to severe symptoms, such as dyspnoea and recurrent pulmonary infections.

The anaesthetic considerations must be individualised, depending on the severity of lung involvement, comorbidities as well as type of surgical procedure. In severe cases, such as that in our patient, anaesthetic management parallels that of patients with obstructive lung disease [2]. Local anaesthesia, regional anaesthesia and central neuraxial anaesthesia should be used whenever possible. Care should be taken to avoid anaesthetising the phrenic nerve in patients with severe disease. As these patients are prone to baro- and volu-trauma, mechanical ventilation should be carefully set to avoid high airway pressures and large tidal volumes in cases when general anaesthesia cannot be avoided [3].

In view of her underlying SJMS, regional anaesthesia was performed to avoid potential postoperative respiratory complications. An incision was to be made at the 0700 position of the lower inner quadrant of the left breast. The combination of single shot paravertebral block at T3 and T4 levels, as well as medial and lateral pectoral nerve blocks was chosen based on the knowledge of the anatomy of the breast. The breast is mainly innervated by the anterolateral and anteromedial branches of the thoracic intercostal nerves corresponding to T3 - T5 and these are being targeted by the paravertebral blocks. Supraclavicular nerves from the lower fibers of the cervical plexus provide innervation to the upper and lateral portions of the breast. Researchers believe sensation to the nipple derives largely from the lateral cutaneous branch of T4 [4]. Medial and lateral pectoral nerve blocks, also known as Pecs I block, were administered to incorporate coverage to pectoralis muscle which lies deep to the breast tissue.

A brief literature search of the MEDLINE database via Pubmed was carried out to review the types of RA performed for breast surgery. Articles were included (Table 1) if RA was performed on patients undergoing breast surgery, published in English and full texts were available. RA performed included paravertebral blocks, Pecs block, serratus plane block, intercostal blocks, superficial cervical plexus block, complete ante-thoracic block, thoracic and cervical epidural anaesthesia, as well as transverse abdominis plane blocks for operations with transverse rectus abdominis myocutaneous (TRAM) flap reconstructions. 
Table 1. Review of regional anaesthesia performed for breast surgery.

\begin{tabular}{|c|c|c|c|c|c|}
\hline First Author (year) & Patient indication & Surgical indication & Type of block & Outcome & Complication \\
\hline Our presented patient & $\begin{array}{l}\text { SJMS with grossly } \\
\text { abnormal lung } \\
\text { function test }\end{array}$ & $\begin{array}{l}\text { Left lower inner } \\
\text { quadrant } \\
\text { lumpectomy }\end{array}$ & $\begin{array}{l}\text { PVB and Pecs I } \\
\text { block }\end{array}$ & $\begin{array}{l}\text { Excellent surgical } \\
\text { condition. Discharged } \\
\text { on the same day. }\end{array}$ & - \\
\hline Moon EJ (2017) [5] & Refusal of GA & $\begin{array}{l}\text { Left breast mass for } \\
\text { Breast-Conserving } \\
\text { Surgery with } \\
\text { Axillary Clearance }\end{array}$ & $\begin{array}{l}\text { Pecs I and II (in } \\
\text { combination with } \\
\text { sedation) }\end{array}$ & $\begin{array}{c}\text { Analgesic effect } \\
\text { lasted } 8 \text { hours } \\
\text { No post-operative } \\
\text { nausea and vomiting } \\
\text { (PONV) }\end{array}$ & - \\
\hline Versyck B. (2017) [6] & $\begin{array}{l}140 \text { patients with } \\
\text { breast cancer } \\
\text { stage } 1-3\end{array}$ & $\begin{array}{l}\text { Mastectomy or } \\
\text { lumpectomy with } \\
\text { sentinel node or } \\
\text { axillary node } \\
\text { dissection }\end{array}$ & $\begin{array}{c}\text { Pecs II block or } \\
\text { placebo block with } \\
\text { saline }\end{array}$ & $\begin{array}{c}\text { Pecs group had } \\
\text { significantly less pain } \\
\text { during stay in recovery } \\
\text { area, required } \\
\text { significantly less } \\
\text { postoperative opioids }\end{array}$ & - \\
\hline Hong B (2017) [7] & $\begin{array}{l}27 \text {-weeks } \\
\text { parturient, with } \\
\text { recurrent breast } \\
\text { cancer, refused } \\
\text { GA }\end{array}$ & $\begin{array}{l}\text { Wide excision of } \\
\text { breast mass } 3-4 \mathrm{~cm} \\
\text { below the clavicle }\end{array}$ & $\begin{array}{l}\text { Pecs II block and } \\
\text { Pecto-intercostal } \\
\text { fascial block }\end{array}$ & $\begin{array}{l}\text { No intraoperative } \\
\text { analgesics. } \\
\text { Postoperative Visual } \\
\text { Analogue Scale (VAS) } \\
\text { score } 1 \text { but did not } \\
\text { require further } \\
\text { analgesics. }\end{array}$ & - \\
\hline $\begin{array}{c}\text { Abdallah FW (2017) } \\
{[8]}\end{array}$ & $\begin{array}{l}\text { Cohort study of } \\
225 \text { patients with } \\
\text { breast cancer }\end{array}$ & $\begin{array}{l}\text { Ambulatory breast } \\
\text { cancer surgery }\end{array}$ & $\begin{array}{l}3 \text { study groups of } \\
\text { (75 per group): } \\
\text { pectoralis, serratus } \\
\text { block and } \\
\text { conventional } \\
\text { opioid-based } \\
\text { analgesia }\end{array}$ & $\begin{array}{l}\text { Pec and SPB associated } \\
\text { with, reduced } \\
\text { intraoperative fentanyl } \\
\text { requirements, expedited } \\
\text { recovery room } \\
\text { discharge, reduced } \\
\text { post-operative opioid } \\
\text { use and PONV } \\
\text { compared to control }\end{array}$ & - \\
\hline Kim H (2017) [9] & Refusal of GA & $\begin{array}{l}\text { Excision of breast } \\
\text { giant fibroadenoma }\end{array}$ & $\begin{array}{l}\text { Pecs I, Pecs II and } \\
\text { internal intercostal } \\
\text { plane block }\end{array}$ & $\begin{array}{l}\text { No intraoperative } \\
\text { opioid needed. } \\
\text { No postoperative pain }\end{array}$ & - \\
\hline $\begin{array}{c}\text { Takahashi H (2017) } \\
{[10]}\end{array}$ & $\begin{array}{l}72 \text { years old, } \\
\text { breast cancer at } 1 \\
\text { o'clock position } \\
\text { of the right breast }\end{array}$ & $\begin{array}{l}\text { Modified radical } \\
\text { mastectomy with } \\
\text { sentinel node } \\
\text { dissection }\end{array}$ & $\begin{array}{c}\text { Complete } \\
\text { ante-thoracic } \\
\text { (medial, inferior, } \\
\text { lateral) block, with } \\
\text { sedation using } \\
\text { propofol and } \\
\text { remifentanil } 0.1 \\
\mathrm{mcg} / \mathrm{kg} / \mathrm{min}\end{array}$ & $\begin{array}{l}\text { No postoperative } \\
\text { analgesics. }\end{array}$ & - \\
\hline Patel SY (2017) [11] & $\begin{array}{l}65 \text { year old with } \\
\text { ductal } \\
\text { carcinoma-in-situ } \\
\text { and mammary } \\
\text { dysplasia, history } \\
\text { of severe PONV }\end{array}$ & $\begin{array}{l}\text { Unilateral } \\
\text { mastectomy and } \\
\text { TRAM flap } \\
\text { reconstruction } \\
\text { without axillary } \\
\text { lymph node } \\
\text { dissection }\end{array}$ & $\begin{array}{l}\text { Pecs I and II, } \\
\text { unilateral } \\
\text { abdominal TAP } \\
\text { block done } \\
\text { before GA }\end{array}$ & $\begin{array}{c}\text { NRS } 4-5 / 10 \text { on the side } \\
\text { not blocked } \\
\text { mild to moderate } \\
\text { nausea } 0-48 \mathrm{hrs} \\
\text { RA lasted } 24 \mathrm{hrs}\end{array}$ & - \\
\hline
\end{tabular}




\section{Continued}

\begin{tabular}{|c|c|c|c|c|c|}
\hline Cata JP (2016) [12] & $\begin{array}{l}\text { Retrospective } \\
\text { study of } 792 \\
\text { non-metastatic } \\
\text { breast cancer to } \\
\text { evaluate if use of } \\
\text { PVB prolongs } \\
\text { their survival }\end{array}$ & Mastectomy & $\begin{array}{c}198 \text { given PVB, } \\
\text { remainder treated } \\
\text { with opioid based } \\
\text { analgesia }\end{array}$ & $\begin{array}{l}\text { Significantly lower } \\
\text { intraoperative } \\
\text { fentanyl consumption } \\
\text { No significant change in } \\
\text { recurrence-free survival }\end{array}$ & - \\
\hline Hards M (2016) [13] & $\begin{array}{l}\text { Retrospective } \\
\text { study of } 27 \text { breast } \\
\text { cancer patients }\end{array}$ & Mastectomy & $\begin{array}{c}16 \text { had serratus } \\
\text { block; } 11 \text { had } \\
\text { wound infiltration }\end{array}$ & $\begin{array}{l}\text { No patients with SPB } \\
\text { had severe pain in } \\
\text { recovery or POD } 1 \\
2 \text { patients who had } \\
\text { wound infiltration } \\
\text { had severe pain } \\
\text { in recovery, and } \\
3 \text { patients on POD1 }\end{array}$ & - \\
\hline Bonomi S (2016) [14] & $\begin{array}{c}\text { Breast cancer } \\
\text { patients }\end{array}$ & $\begin{array}{l}\text { Implant-based } \\
\text { breast } \\
\text { reconstructions }\end{array}$ & $\begin{array}{c}\text { Bilateral Pecs block, } \\
\text { with GA }\end{array}$ & $\begin{array}{c}\text { Eliminated need for } \\
\text { post-operative opoid } \\
\text { no PONV } \\
\text { lower mean VAS score } \\
\text { throughout } \\
\text { inpatient stay }\end{array}$ & - \\
\hline Fallatah S (2016) [15] & $\begin{array}{c}40 \text { patients with } \\
\text { unilateral breast } \\
\text { cancer }\end{array}$ & $\begin{array}{l}\text { Unilateral } \\
\text { lumpectomy and } \\
\text { axillary lymph } \\
\text { nodes dissection }\end{array}$ & $\begin{array}{l}20 \text { patients received } \\
\text { peroperative } \\
\text { unilateral PVB from } \\
\text { T2-6; } 20 \text { patients } \\
\text { received } \\
\text { postoperative } \\
\text { PCA morphine; } \\
\text { both with GA }\end{array}$ & $\begin{array}{l}\text { Significantly lower pain } \\
\text { scores, shorter hospital } \\
\text { stay, higher satisfaction } \\
\text { score, and less PONV in } \\
\text { patients who had PVB }\end{array}$ & $\begin{array}{l}2 \text { patients who had } \\
\text { PVB had } \\
\text { inadvertent vascular } \\
\text { puncture and one } \\
\text { with pain at the site } \\
\text { of injection that } \\
\text { continued beyond a } \\
\text { month }\end{array}$ \\
\hline Wolf O (2016) [16] & $\begin{array}{l}\text { RCT involving } 74 \\
\text { breast cancer } \\
\text { patients }\end{array}$ & $\begin{array}{l}\text { Prosthetic breast } \\
\text { reconstruction }\end{array}$ & $\begin{array}{l}\text { PVB with GA or } \\
\text { GA alone }\end{array}$ & $\begin{array}{l}\text { Significantly less } \\
\text { intraoperative and } \\
\text { postoperative opioid } \\
\text { consumption } \\
\text { Less antiemetic } \\
\text { medication }\end{array}$ & - \\
\hline Khemka R (2016) [17] & $\begin{array}{l}2 \text { patients with } \\
\text { unilateral breast } \\
\text { malignancy }\end{array}$ & $\begin{array}{l}\text { breast conservation } \\
\text { surgery with } \\
\text { dissection of the } \\
\text { axillary nodes } \\
\text { followed by } \\
\text { reconstruction } \\
\text { using a LD } \\
\text { pedicle flap }\end{array}$ & $\begin{array}{c}\text { Pecs I block and } \\
\text { serratus anterior } \\
\text { plane block with } \\
\text { GA }\end{array}$ & $\begin{array}{c}\text { No intraoperative } \\
\text { opioid. } 1 \text { had } 6 \mathrm{mg} \\
\text { morphine } 0-48 \mathrm{hs} \text {. The } \\
\text { other had } 4 \mathrm{mg} \text { of } \\
\text { morphine } 0-48 \mathrm{hs}\end{array}$ & - \\
\hline Fusco P (2016) [18] & $\begin{array}{l}78 \text { year old severe } \\
\text { respiratory } \\
\text { insufficiency } \\
\text { for pulmonary } \\
\text { fibrosis }\end{array}$ & $\begin{array}{l}\text { Radical mastectomy } \\
\text { and axillary } \\
\text { dissection }\end{array}$ & $\begin{array}{l}\text { Serratus plane } \\
\text { block, PECS I block, } \\
\text { parasternal LA } \\
\text { injections }\end{array}$ & $\begin{array}{l}\text { Complete anaesthesia of } \\
\text { mammary and } \\
\text { axillary regions. } \\
\text { No opioids first } \\
24 \text { hs of surgery }\end{array}$ & - \\
\hline
\end{tabular}




\section{Continued}

\begin{tabular}{|c|c|c|c|c|c|}
\hline Shah A (2015) [19] & $\begin{array}{l}\text { Retrospective } \\
\text { review involving } \\
132 \text { patients }\end{array}$ & $\begin{array}{l}\text { Implant-based } \\
\text { breast } \\
\text { reconstruction }\end{array}$ & $\begin{array}{c}\text { Intercostal nerve } \\
\text { blockade }\end{array}$ & $\begin{array}{l}\text { Significant reduction in } \\
\text { length of stay, } \\
\text { consumption of } \\
\text { intravenous morphine } \\
\text { and increased } \\
\text { cost-savings }\end{array}$ & - \\
\hline $\begin{array}{l}\text { Sundarathiti P (2015) } \\
\text { [20] }\end{array}$ & $\begin{array}{l}\text { RCT involving } 70 \\
\text { breast cancer } \\
\text { patients }\end{array}$ & $\begin{array}{c}\text { Unilateral } \\
\text { mastectomy surgery } \\
\text { with axillary } \\
\text { dissection }\end{array}$ & $\begin{array}{l}\text { GA or PVB via } \\
\text { catheter and } \\
\text { injections at } 3 \\
\text { different levels }\end{array}$ & $\begin{array}{l}\text { Analgesic consumption, } \\
\text { post-operative pain } \\
\text { scores significantly } \\
\text { greater in patients } \\
\text { with GA }\end{array}$ & - \\
\hline $\begin{array}{c}\text { Kulkarni K (2013) } \\
\text { [21] }\end{array}$ & $\begin{array}{l}40 \text { ASA I and II } \\
\text { patients with } \\
\text { breast cancer }\end{array}$ & $\begin{array}{c}\text { Radical } \\
\text { mastectomies }\end{array}$ & $\begin{array}{l}\text { Cervical epidural } \\
\text { anaesthesia with } \\
\text { either } 10 \mathrm{mls} \text { of } \\
0.25 \% \text { bupivacaine } \\
\text { or } 10 \mathrm{mls} \text { of } \\
0.375 \% \text { ropivacaine }\end{array}$ & $\begin{array}{l}\text { Similar onset of } \\
\text { sensory block } \\
\text { Significant increase in } \\
\text { mean motor blockade } \\
\text { score, time to achieve } \\
\text { complete blockade and } \\
\text { time to grade I motor } \\
\text { recovery for patients } \\
\text { who received } \\
\text { bupivacaine }\end{array}$ & $\begin{array}{c}\text { Respiratory } \\
\text { distress in } 2 \\
\text { patients } \\
\text { requiring } \\
\text { GA with intubation }\end{array}$ \\
\hline Coopey SB (2013) [22] & $\begin{array}{l}\text { Retrospective } \\
\text { review of breast } \\
\text { cancer patients }\end{array}$ & $\begin{array}{l}\text { Mastectomies with } \\
\text { immediate } \\
\text { reconstructions }\end{array}$ & PVB & $\begin{array}{l}\text { Significantly less mean } \\
\text { length of stay, shorter } \\
\text { mean time to } \\
\text { conversion to oral } \\
\text { narcotics, less incidence } \\
\text { of PONV in PVB group }\end{array}$ & - \\
\hline Moller JF (2007) [24] & $\begin{array}{l}\text { RCT involving } 88 \\
\text { breast cancer } \\
\text { patients }\end{array}$ & $\begin{array}{l}\text { Breast tumour } \\
\text { resection or } \\
\text { mastectomy with } \\
\text { lymph node } \\
\text { biopsy }\end{array}$ & $\begin{array}{l}\text { GA and } \\
\text { paravertebral } \\
\text { injections with } \\
\text { either } 0.5 \% \\
\text { ropivacaine } \\
\text { or saline }\end{array}$ & $\begin{array}{l}\text { Postoperative } \\
\text { consumption of IV } \\
\text { fentanyl and number of } \\
\text { patients who reported } \\
\text { pain }>3 \text { on NRS were } \\
\text { significantly less in the } \\
\text { Ropivacaine group }\end{array}$ & - \\
\hline Singh AP (2006) [25] & $\begin{array}{l}50 \text { ASA } 1 \text { or } 2 \\
\text { breast cancer } \\
\text { patients }\end{array}$ & $\begin{array}{l}\text { Modified radical } \\
\text { mastectomies }\end{array}$ & $\begin{array}{c}\text { Cervical epidural } \\
\text { anaesthesia with } 10 \\
\text { mls of } 1 \% \\
\text { lignocaine followed } \\
\text { by } 0.125 \% \\
\text { bupivacaine } \\
\text { through epidural } \\
\text { catheter }\end{array}$ & $\begin{array}{l}\text { No clinically significant } \\
\text { variations in } \\
\text { perioperative pulse } \\
\text { and respiratory rate } \\
\text { No fall in mean arterial } \\
\text { blood pressure during } \\
\text { operation }\end{array}$ & $\begin{array}{l}\text { One case where the } \\
\text { procedure was } \\
\text { terminated due to } \\
\text { accidental dura } \\
\text { puncture. }\end{array}$ \\
\hline $\begin{array}{c}\text { Exadaktylos AK } \\
\text { (2006) [26] }\end{array}$ & $\begin{array}{l}\text { Retrospective } \\
\text { study of } 129 \\
\text { patients with } \\
\text { breast cancer }\end{array}$ & $\begin{array}{l}\text { Mastectomy and } \\
\text { axillary clearance }\end{array}$ & $\begin{array}{c}50 \text { patients had PVB } \\
\text { with GA; } 79 \\
\text { patients had GA } \\
\text { with morphine } \\
\text { analgesia }\end{array}$ & $\begin{array}{l}\text { Recurrence- and } \\
\text { metastasis-free survival } \\
\text { was significantly higher } \\
\text { in the PVB patients }\end{array}$ & - \\
\hline
\end{tabular}




\section{Continued}

\section{Kolawole IK (2006) \\ [27] 2. 60 years old left breast mass with}

\section{Kairaluoma PM (2004) [28]}

Stamatiou G (2004) [29]

Buckenmaier CC 3rd (2002) [30]

D'Ercole FJ (1999)

Atanassoff PG (1994) [32]

\section{55 years old patient with recurrent left breast tumour with lung metastasis complicated by pleural effusion and pneumonia widespread lung metastasis}

60 breast cancer patients

24 years old, 14 weeks of gestation, with left breast tumour

72 year old patient with HOCM, emphysema on home oxygen therapy

38 year old, 29 weeks of gestation with a $10 \mathrm{~cm}$ left breast mass

RCT involving 48 ASA I and II patients
Palliative simple mastectomy

Breast resection or mastectomy with and without associated axillary dissection

Wide local excision of tumour and lymph node dissection

Left partial mastectomy with axillary dissection for infiltrating ductal carcinoma

Left modified radical mastectomy with axillary dissection

Left paravertebral nerve blocks at

T1-T6

Left paravertebral nerve blocks at

thoracic levels 1 - 6; left superficial cervical plexus block

groups of patients receiving intercostal nerve blockade of T3-6 unilaterally with either $1.5 \%$ or $2 \%$ lidocaine or $0.5 \%$ bupivacaine. $4^{\text {th }}$ group was control who received GA lumpectomy

1) pain-free for 5 hours 2) Uneventful postoperative course

Significantly less post-operative opioid medication, less pain after $24 \mathrm{~h}$, less PONV in the bupivacaine group

Tolerated $65 \mathrm{~min}$ of operation under sedation with propofol infusion Total analgesic requirement was $12 \mathrm{mg}$ morphine and $5 \mathrm{~g}$ paracetamol

for the first $48 \mathrm{hs}$

Pain free and opioid free on day of operation $4 \mathrm{mg}$ of IV morphine on POD1

Discharged pain free subsequently

Tolerated procedure Oral non-opioid analgesia $18 \mathrm{~h}$ after neural blockade Discharged on POD2

Significantly higher postoperative pain scores in control group. Number of women requiring post-operative analgesia, total amount of analgesics given during 24 hs post operatively were significantly lower in

RA group
Hypotension, attribulated to sedation and possibly hypovolemia from fasting; resolved after fluid challenge
One patient had bilateral convulsions right after bupivacaine injection 
Several randomised controlled trials [15] [16] [20] [24] [28], comparing the use of PVB and GA to that of GA alone in patients undergoing breast surgeries, showed significant reduction in post-operative pain, post-operative opioid consumption and occurrence of post-operative nausea and vomiting (PONV) in patients receiving $\mathrm{PVB}$. A recent randomised control trial conducted by Versyck $\mathrm{B}$ [6] comparing the more novel Pecs II block to placebo block in patients undergoing mastectomy or lumpectomy with axillary node dissection showed significant reduction in pain scores and postoperative opioid use. Other positive outcomes from the review include reduction in length of hospital stay (LOS), increased cost-savings and an increase in satisfaction score. On the other hand, complications were much less frequently described, signifying a favourable risk-benefit ratio of RA. Use of RA avoided post-operative respiratory complications, such as atelectasis, pneumonia and consequently, respiratory failure, associated with use of GA, especially in our patient with SJMS. It also had advantages over thoracic epidural in its ability to maintain haemodynamic stability, preserve lower limb motor power and hence, to allow for same-day discharge.

R. Blanco, who developed the Pecs I and II blocks, came up with the description of the serratus plane block (SPB), which blocks primarily the thoracic intercostal nerves and provides complete analgesia to the lateral part of the thorax [33]. A prospective observational study [34] conducted to compare paravertebral and serratus plane block in patients scheduled for non-reconstructive breast surgery showed no significant differences between the 2 groups in terms of quality of post-anaesthetic recovery, signifying that it could have been an alternative to the paravertebral block. When compared to PVB, Pecs block and SPB could eliminate the risk of posterior midline spread and subsequent hypotension. Pecs block and SPB may also be more advantageous for anticoagulated patients as according to ASRA's evidence-based guidelines, the same precautions should be taken when placing thoracic PVB as when placing an epidural [35]. However, similar to Pecs II block, SPB targets the lateral cutaneous branches of the intercostal nerves and may not sufficiently provide coverage to our patient whose tumour was in the lower inner quadrant of the breast.

Regional techniques have frequently been performed as an adjunct to GA, but there have been less data on it being given as the sole anaesthesia for breast surgery. The use of a thoracic paravertebral block at T1-3 levels with $3 \mathrm{ml}$ solution of $0.75 \%$ ropivacaine at each level was described in a left quadrantectomy with axillary lymph node dissection for infiltrating ductal carcinoma in a patient who is at a late stage of amyotrophic lateral sclerosis. No other analgesia was given during the 110-min surgery and for 34 hours post-surgery [36]. Ultrasound-guided Pecs II block and internal intercostal plane block were given for excision of breast giant fibroadenoma in a patient who refused general anaesthesia. 10 and $20 \mathrm{mls}$ of $0.375 \%$ ropivacaine was injected for Pecs I and Pecs II block respectively, followed by $10 \mathrm{mls}$ of $0.375 \%$ ropivacaine injected for internal intercostal plane block, with propofol infusion given for sedation to the patient 
who tolerated 1.5 hours of surgical time [9].

RA, either used alone or as an adjunct to GA, can also be recommended for well patients for the benefit it carries. Basic sciences studies and a retrospective review have suggested that breast cancer patients had better cancer outcomes if they received paravertebral blocks with GA compared to those who had received GA alone [26], although this benefit has yet to be shown in recent studies [11]. A multicentre double-blinded randomised trial (https://www.clinicaltrials.gov/, NCT00418457) is currently underway to determine the rate of cancer recurrence or metastasis in breast cancer patients receiving either RA or GA. Large majority of studies have shown that regional technique reduces intraoperative use of opioids and post-operative pain [16] [37] [38]. A randomised controlled trial [39] with PVB and placebo in patients undergoing mastectomies have not shown that use of RA to be associated with less incidence of chronic pain. There was, however, less severe chronic pain in patients who received PVB, and they too, experienced better physical and mental health-related quality of life compared to patients who received placebo injections. Other benefits of giving RA with or without GA include lower incidence of post-operative nausea and vomiting related to reduced usage of opioids [8] [40] [41], improved patient satisfaction score [39] and reduction in length of hospital stay [22] [40].

Regional anaesthesia has proven to be the safest approach in circumstances where GA would have carried a much higher risk. A patient with Eisenmenger's syndrome had surgical resection of a carotid body tumour done successfully under continuous cervical plexus block and remifentanil infusion, avoiding GA and its associated haemodynamic complications [42]. A supraclavicular block as a sole anaesthetic technique for an elbow incision and drainage procedure for one of a pair of adult craniopagus twins is another example where RA is more ideal than GA. They would otherwise be subjected to unpredictable effects of anaesthetic crossover and potential difficult airway due to anatomy differences. [43] Simultaneous bilateral below-knee amputations were performed under ultrasound-guided combined inguinal femoral and subgluteal sciatic nerve blocks in a coagulopathic patient with chronic ischaemic heart disease [44]. Left below-knee amputation, which took 76 mins, was performed under ultrasound-guided left femoral nerve block and left subgluteal sciatic nerve block using $21 \mathrm{ml}$ and $24 \mathrm{ml}$ of local anaesthetic mixture (containing 1:1 ratio of $1 \%$ mepivacaine and $0.75 \%$ ropivacaine) respectively. Subsequently, similar blocks using a total of $47 \mathrm{ml}$ of the same local anaesthetic mixture was performed for the right below-knee amputation. Sequential placement of the blocks before corresponding limb surgery allowed successful anaesthesia without local anaesthesia toxicity, and at the same time, avoiding the high risk of GA in this patient.

Apart from the patient's medical condition and choice when considering method of anaesthesia, other practical issues include patient comfort and the ability to provide ideal operating conditions. RA can be combined with sedation to improve intra-operative patient comfort. However, gentle surgical manipula- 
tion is required and this may not be well-received by all surgeons. Consequences of potential complications resulting from RA have to be taken into consideration. In this particular patient, it would have been disastrous if a pneumothorax were to result from PVB in the only functional lung.

\section{Conclusion}

Regional block with sedation is a feasible anaesthetic option for patients going for breast surgeries and this can reduce perioperative respiratory risks dramatically in patients with severe lung pathology. In addition, it may also be recommended to well patients as RA may improve other aspects of postoperative recovery, such as better pain control, lower incidence of PONV, shorter length of stay, which may all indirectly increase cost savings. However, there are other considerations such as surgeon's and patient's acceptability before making RA the default technique for breast operations.

\section{Financial Disclosures}

None.

\section{Conflicts of Interest}

None.

\section{References}

[1] Sulaiman, A., Cavaille, A., Vaunois, B., et al. (2009) Swyer-James-MacLeod Syndrome; Repeated Chest Drainages in a Patient Misdiagnosed with Pneumothorax. Interactive Cardiovascular and Thoracic Surgery, 8, 482-484. https://doi.org/10.1510/icvts.2008.197566

[2] Smith, M.M., Barbara, D.W., Smith, B.C., et al. (2014) Anesthetic Implications for Patients with Swyer-James Syndrome. Journal of Cardiothoracic and Vascular Anesthesia, 28, 925-930. https://doi.org/10.1053/j.jvca.2013.03.039

[3] Licker, M., Schweizer, A., Ellenberger, C., et al. (2007) Perioperative Medical Management of Patients with COPD. International Journal of Chronic Obstructive Pulmonary Disease, 2, 493-515.

[4] Sarhadi, N.S., Shaw Dunn, J., Lee, F.D., et al. (1996) An Anatomical Study of the Nerve Supply of the Breast, Including the Nipple and Areola. British Journal of Plastic Surgery, 49, 156-164.

[5] Moon, E.J., Kim, S.B., Chung, J.Y., et al. (2017) Pectoral Nerve Block (Pecs Block) with sedation for Breast Conserving Surgery without General Anesthesia. Annals of Surgical Treatment and Research, 93, 166-169.

https://doi.org/10.4174/astr.2017.93.3.166

[6] Versyck, B., van Geffen, G.J. and Van Houwe, P. (2017) Prospective Double Blind Randomized Placebo-Controlled Clinical Trial of the Pectoral Nerves (Pecs) Block Type II. Journal of Clinical Anesthesia, 40, 46-50. https://doi.org/10.1016/j.jclinane.2017.03.054

[7] Hong, B., Yoon, S.H., Youn, A.M., et al. (2017) Thoracic Interfascial Nerve Block for Breast Surgery in a Pregnant Woman: A Case Report. Korean Journal of Anesthesiology, 70, 209-212. https://doi.org/10.4097/kjae.2017.70.2.209 
[8] Abdallah, F.W., MacLean, D., Madjdpour, C., et al. (2017) Pectoralis and Serratus Fascial Plane Blocks Each Provide Early Analgesic Benefits Following Ambulatory Breast Cancer Surgery: A Retrospective Propensity-Matched Cohort Study. Anesthesia \& Analgesia, 125, 294-302. https://doi.org/10.1213/ANE.0000000000001975

[9] Kim, H., Shim, J. and Kim, I. (2017) Surgical Excision of the Breast Giant Fibroadenoma under Regional Anesthesia by Pecs II and Internal Intercostal Plane Block: A Case Report and Brief Technical Description: A Case Report. Korean Journal of Anesthesiology, 70, 77-80. https://doi.org/10.4097/kjae.2017.70.1.77

[10] Takahashi, H. and Suzuki, T. (2017) Complete Antethoracic Block for Analgesia after Modified Radical Mastectomy: A Case Report. A\&A Case Reports, 8, 250-253.

[11] Patel, S.Y., Evans, R.M., Garcia Getting, R.E., et al. (2017) Pectoral Nerve and Transverse Abdominis Plane Block in a Patient Undergoing Mastectomy with Transverse Rectus Abdominis Muscle Flap: A Case Report. A \& A Case Reports, 8 , 210-212.

[12] Cata, J.P., Chavez-MacGregor, M., et al. (2016) The Impact of Paravertebral Block Analgesia on Breast Cancer Survival after Surgery. Regional Anesthesia and Pain Medicine, 41, 696-703. https://doi.org/10.1097/AAP.0000000000000479

[13] Hards, M., Harada, A., Neville, I., et al. (2016) The Effect of Serratus Plane Block Performed under Direct Vision on Postoperative Pain in Breast Surgery. Journal of Clinical Anesthesia, 34, 427-431. https://doi.org/10.1016/j.jclinane.2016.05.029

[14] Bonomi, S., Salval, A. and Crippa, S. (2016) Ultrasound-Guided Thoracic Wall Nerve Blocks to Reduce Postoperative Pain and Eliminate Opioid Consumption in Patients Undergoing Implant-Based Breast Reconstruction. Plastic and Reconstructive Surgery, 138, 543e-544e. https://doi.org/10.1097/PRS.0000000000002436

[15] Fallatah, S. and Mousa, W.F. (2016) Multiple Levels Paravertebral Block versus Morphine Patient-Controlled Analgesia for Postoperative Analgesia Following Breast Cancer Surgery with Unilateral Lumpectomy, and Axillary Lymph Nodes Dissection. Saudi Journal of Anaesthesia, 10, 13-17. https://doi.org/10.4103/1658-354X.169468

[16] Wolf, O., Clemens, M.W., Purugganan, R.V., et al. (2016) A Prospective, Randomized, Controlled Trial of Paravertebral Block versus General Anesthesia Alone for Prosthetic Breast Reconstruction. Plastic and Reconstructive Surgery, 137, 660e-666e. https://doi.org/10.1097/01.prs.0000481070.79186.0d

[17] Khemka, R., Chakraborty, A., Ahmed, R., et al. (2016) Ultrasound-Guided Serratus Anterior Plane Block in Breast Reconstruction Surgery. A \& A Case Reports, 6, 280-282.

[18] Fusco, P., Scimia, P., Marinangeli, F., et al. (2016) The Association between the Ultrasound-Guided Serratus Plane Block and PECS I Block Can Represent a Valid Alternative to Conventional Anesthesia in Breast Surgery in a Seriously Ill Patient. Minerva Anestesiologica, 82, 241-242.

[19] Shah, A., Rowlands, M., Krishnan, N., et al. (2015) Thoracic Intercostal Nerve Blocks Reduce Opioid Consumption and Length of Stay in Patients Undergoing Implant-Based Breast Reconstruction. Plastic and Reconstructive Surgery, 136, 584e-591e. https://doi.org/10.1097/PRS.0000000000001717

[20] Sundarathiti, P., von Bormann, B., Suvikapakornkul, R., et al. (2015) Paravertebral Catheter for Three-Level Injection in Radical Mastectomy: A Randomised Controlled Study. PLOS ONE, 10, e0129539. https://doi.org/10.1371/journal.pone.0129539

[21] Kulkarni, K., Namazi, I.J., Deshpande, S., et al. (2013) Cervical Epidural Anaesthesia 
with Ropivacaine for Modified Radical Mastectomy. Kathmandu University Medical Journal, 11, 126-131.

[22] Coopey, S.B., Specht, M.C., Warren, L., et al. (2013) Use of Preoperative Paravertebral Block Decreases Length of Stay in Patients Undergoing Mastectomy plus Immediate Reconstruction. Annals of Surgical Oncology, 20, 1282-1286. https://doi.org/10.1245/s10434-012-2678-7

[23] Li, N.L., Yu, B.L., Tseng, S.C., et al. (2011) The Effect on Improvement of Recovery and Pain Scores of Paravertebral Block Immediately before Breast Surgery. Acta Anaesthesiologica Taiwanica, 49, 91-95. https://doi.org/10.1016/j.aat.2011.08.006

[24] Moller, J.F., Nikolajsen, L., Rodt, S.A., et al. (2007) Thoracic Paravertebral Block for Breast Cancer Surgery: A Randomized Double-Blind Study. Anesthesia \& Analgesia, 105, 1848-1851. https://doi.org/10.1213/01.ane.0000286135.21333.fd

[25] Singh, A.P., Tewari, M., Singh, D.K., et al. (2006) Cervical Epidural Anesthesia: A Safe Alternative to General Anesthesia for Patients Undergoing Cancer Breast Surgery. World Journal of Surgery, 30, 2043-2047. https://doi.org/10.1007/s00268-006-0117-2

[26] Exadaktylos, A.K., Buggy, D.J., Moriarty, D.C., et al. (2006) Can Anesthetic Technique for Primary Breast Cancer Surgery Affect Recurrence or Metastasis? Anesthesiology, 105, 660-664. https://doi.org/10.1097/00000542-200610000-00008

[27] Kolawole, I.K., Adesina, M.D. and Olaoye, I.O. (2006) Intercostal Nerves Block for Mastectomy in Two Patients with Advanced Breast Malignancy. Journal of the National Medical Association, 98, 450-453.

[28] Kairaluoma, P.M., Bachmann, M.S., Korpinen, A.K., et al. (2004) Single-Injection Paravertebral Block before General Anesthesia Enhances Analgesia after Breast Cancer Surgery with and without Associated Lymph Node Biopsy. Anesthesia \& Analgesia, 99, 1837-1843. https://doi.org/10.1213/01.ANE.0000136775.15566.87

[29] Stamatiou, G., Athanasiou, E., Simeoforidou, M., et al. (2004) Thoracic Paravertebral Block for Breast Surgery. Anaesthesia, 59, 723-724. https://doi.org/10.1111/j.1365-2044.2004.03848.x

[30] Buckenmaier, C.C., Steele, S.M., Nielsen, K.C., et al. (2002) Paravertebral Somatic nerve Blocks for Breast Surgery in a Patient with Hypertrophic Obstructive Cardiomyopathy. Canadian Journal of Anesthesia, 49, 571-574.

https://doi.org/10.1007/BF03017383

[31] D’Ercole, F.J., Scott, D., Bell, E., et al. (1999) Paravertebral Blockade for Modified Radical Mastectomy in a Pregnant Patient. Anesthesia \& Analgesia, 88, 1351-1353. https://doi.org/10.1213/00000539-199906000-00029

[32] Atanassoff, P.G., Alon, E. and Weiss, B.M. (1994) Intercostal Nerve Block for Lumpectomy: Superior Postoperative Pain Relief with Bupivacaine. Journal of Clinical Anesthesia, 6, 47-51. https://doi.org/10.1016/0952-8180(94)90118-X

[33] Blanco, R., Parras, T., McDonnell, J.G., et al. (2013) Serratus Plane Block: A Novel Ultrasound-Guided Thoracic Wall Nerve Block. Anaesthesia, 68, 1107-1113. https://doi.org/10.1111/anae.12344

[34] Pérez Herrero, M.A., LópezÁlvarez, S., Fadrique Fuentes, A., et al. (2016) Quality of Postoperative Recovery after Breast Surgery. General Anaesthesia Combined with Paravertebral versus Serratus-Intercostal Block. Revista Espanola De Anestesiologia $Y$ Reanimacion, 63, 564-571. https://doi.org/10.1016/j.redar.2016.03.006

[35] Horlocker, T.T., Wedel, D.J., Rowlingson, J.C., et al. (2010) Regional Anesthesia in the Patient Receiving Antithrombotic or Thrombolytic Therapy: American Society of Regional Anesthesia and Pain Medicine Evidence-Based Guidelines. 3rd Edition, 
Regional Anesthesia and Pain Medicine, 35, 64-101. https://doi.org/10.1097/AAP.0b013e3181c15c70

[36] Agnoletti, V., Corso, R., Cattano, D., et al. (2013) Thoracic Paravertebral Block for Breast Surgery in a Patient with Amyotrophic Lateral Sclerosis. Minerva Anestesiologica, 79, 822-823.

[37] Terkawi, A.S., Tsang, S., Sessler, D.I., et al. (2015) Improving Analgesic Efficacy and Safety of Thoracic Paravertebral Block for Breast Surgery: A Mixed-Effects Meta-Analysis. Pain Physician, 18, E757-E780.

[38] Wu, J., Buggy, D., Fleischmann, E., et al. (2015) Thoracic Paravertebral Regional Anesthesia Improves Analgesia after Breast Cancer Surgery: A Randomized Controlled Multicentre Clinical Trial. Canadian Journal of Anesthesia, 62, 241-251. https://doi.org/10.1007/s12630-014-0285-8

[39] Karmakar, M.K., Samy, W., Li, J.W., et al. (2014) Thoracic Paravertebral Block and Its Effects on Chronic Pain and Health-Related Quality of Life after Modified Radical Mastectomy. Regional Anesthesia and Pain Medicine, 39, 289-298. https://doi.org/10.1097/AAP.0000000000000113

[40] Tahiri, Y., Tran, D.Q., Bouteaud, J., et al. (2011) General Anaesthesia versus Thoracic Paravertebral Block for Breast Surgery: A Meta-Analysis. Journal of Plastic, Reconstructive \& Aesthetic Surgery, 64, 1261-1269. https://doi.org/10.1016/j.bjps.2011.03.025

[41] Fahy, A.S., Jakub, J.W., Dy, B.M., et al. (2014) Paravertebral Blocks in Patients Undergoing Mastectomy with or without Immediate Reconstruction Provides Improved Pain Control and Decreased Postoperative Nausea and Vomiting. Annals of Surgical Oncology, 21, 3284-3289. https://doi.org/10.1245/s10434-014-3923-Z

[42] Jones, H.G. and Stoneham, M.D. (2006) Continuous Cervical Plexus Block for Carotid Body Tumour Excision in a Patient with Eisenmenger's Syndrome. Anaesthesia, 61, 1214-1218. https://doi.org/10.1111/j.1365-2044.2006.04860.x

[43] Schleelein, L.E., Perate, A.R. and Ganesh, A. (2013) Supraclavicular Block as a Sole Anesthetic Technique in Craniopagus Twins. Regional Anesthesia and Pain Medicine, 38, 456-458. https://doi.org/10.1097/AAP.0b013e318296227e

[44] Byun, S.H., Lee, J. and Kim, J.H. (2016) Ultrasound-Guided Bilateral Combined Inguinal Femoral and Subgluteal Sciatic Nerve Blocks for Simultaneous Bilateral Below-Knee Amputations due to Bilateral Diabetic Foot Gangrene Unresponsive to Peripheral Arterial Angioplasty and Bypass Surgery in a Coagulopathic Patient on Antiplatelet Therapy with a History of Percutaneous Coronary Intervention for Ischemic Heart Disease: A Case Report. Medicine (Baltimore), 95, e4324.

https://doi.org/10.1097/MD.0000000000004324 